Scientific journal

PHYSICAL AND MATHEMATICAL EDUCATION

Has been issued since 2013.

Науковий журнал

ФІЗИКО-МАТЕМАТИЧНА ОСВІТА

Видається з 2013.
ISSN 2413-158X (online)

ISSN 2413-1571 (print)

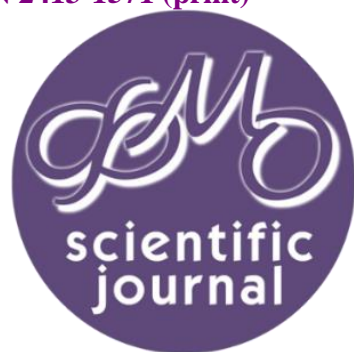

Микитенко П.В., Кучеренко І.І. Використання систем управління навчальними матеріалами в процесі інформатичної підготовки студентів медичних університетів. Фізико-математична освіта. 2021. Випуск 2(28). С. 63-70.

Mykytenko P., Kucherenko I. Use of study material management systems in the process of informatical training of medical university students. Physical and Mathematical Education. 2021. Issue 2(28). P. 63-70.

DOI 10.31110/2413-1571-2021-028-2-011

Удк 004.77:37.02

П.В. Микитенко

Національний медичний університет імені О.О. Богомольчя, Україна mikitenko_p@npu.edu.ua

ORCID: 0000-0003-1188-4334

I.I. Кучеренко

Національний медичний університет імені О.О. Богомольчя, Україна

inna_kucherenko@nmu.ua

ORCID: 0000-0002-0734-6544

\title{
ВИКОРИСТАННЯ СИСТЕМ УПРАВЛІННЯ НАВЧАЛЬНИМИ МАТЕРІАЛАМИ В ПРОЦЕСІ ІНФОРМАТИЧНОЇ ПІДГОТОВКИ
} СТУДЕНТІВ МЕДИЧНИХ УНІВЕРСИТЕТІВ

АНОТАЦІЯ

Формування проблеми. У роботі розглядаються теоретичні та практичні аспекти застосування систем управління навчальними матеріалами. Зважаючи на значний педагогічний потенціал та умови сьогодення, беззаперечно, актуальними є питання щодо побудови моделей, розробки методів і методик та пошуку ефективних шляхів впровадження систем управління навчальними матеріалами в процес інформатичної підготовки студентів медичних 3 ВО.

методи. Для виконання поставлених завдань дослідження було використано комплекс наукових методів досліджень, а саме: метод системного аналізу, бібліосемантичний метод, емпіричні методи та моделювання.

Результати. Обгрунтовано доцільність впровадження систем управління навчальними матеріалами та здійснено виклад загальних принципів їх застосування. Висвітлено компоненти методичної системи інформатичної підготовки, зокрема, визначено чілі та завдання навчання інформатичних дисциплін в медичних ЗВО. Досліджено критерії, що висуваються до систем управління навчальними матеріалами та проаналізовано можливості їх використання. Виокремлено низку функціональних характеристик з метою встановлення найефективнішої системи та здійснено їх порівняльний аналіз.

Висновки. Встановлено, що LCMS Moodle ma Google Classroom мають споріднене завдання - організація та управління навчальним процесом, однак вони володіють і низкою відмінностей в функціональних можливостях. Проте, компенсувати відсутність певних можливостей можна завдяки комбінованому використанню окремих елементів цих систем. У сучасній системі організації навчального процесу в медичних закладах вищої освіти застосування технологій дистанційного навчання є невід'ємною умовою забезпечення якісної підготовки майбутніх фахівців. Використання систем управління навчальними матеріалами, зокрема, хмарних сервісів розширює можливості організаціі дистанційного навчання, надає нові можливості для більш активного залучення студентів в освітній процес, сприяє підвищенню рівня загальнокультурної обізнаності майбутніх фахівців.

кЛЮчовІ СловА: система управління навчальним матеріалом, хмарно-орієнтована система, інформатична підготовка, дистанційне навчання.

ВСТУП

Постановка проблеми. На сьогоднішній день переважна більшість закладів вищої освіти та інших організацій, пропонують свої освітні послуги в глобальній мережі Інтернет. Окрім головного чинника, який спонукає до цього глобальної інформатизації суспільства, з'являється низка нових умов пов'язаних із пандемією. Для забезпечення неперервного функціонування закладів освіти виникає потреба у використанні сучасних засобів для управління інформаційними ресурсами та навчальними матеріалами в закладах вищої освіти, не $є$ винятком і медичні ЗВО. Такими засобами можуть бути системи управління навчальними матеріалами, які $\epsilon$ найбільш доречними для використання в закладі вищої освіти, зокрема під час навчання інформатичних дисциплін.

(C) П.В. Микитенко, І.І. Кучеренко, 2021. 
Розвиток комп'ютерних технологій та їх впровадження в медичну галузь і охорону здоров'я обумовлює необхідність набуття медичними працівниками відповідних практичних навичок при здійсненні аналізу захворюваності пацієнтів, ведення медичної документації, опрацюванні медичних та соціальних даних. Одним із елементів професійної майстерності сучасного медичного працівника, $є$ інформаційно-технологічна компетентність (IT-компетентність) або навички використання інформаційних і комунікаційних технологій, які належать до загальних компетентностей.

Провідним напрямком сучасних досліджень $€$ пошук та впровадження в освітній процес систем, в яких зручно $\mathrm{i}$ ефективно можна організувати структуру навчального курсу (дисципліни) із забезпеченням універсальності та мобільності.

Аналіз останніх досліджень і публікацій. Дослідженню психолого-педагогічних аспектів використання інформаційно-комунікаційних технологій в навчальному процесі та їх потенціалу, зокрема й систем управління навчальним матеріалам, присвячені праці В. Бикова (дослідження проблем проєктування, впровадження та використання відкритого хмаро орієнтованого освітньо-наукового середовища закладу вищої освіти), А. Гуржія (аналіз інформатизації загальної середньої та вищої освіти в Україні), М. Жалдака (дослідження деяких особливостей інформатичної термінології), Н. Морзе (розроблення моделі організації ефективного навчального середовища університету 3 використанням wiki-технології), С. Семерікова (розробка таксономії середовищ дослідження, визначення підходів до їх розвитку і виділення факторів розвитку мобільного навчального середовища), О. Спіріна (визначення критеріїв та встановлення відповідних показників добору відкритих web-орієнтованих технологій навчання), Ю. Триуса (дослідження питань створення систем підтримки дистанційного навчання медичних працівників), В. Франчука (аналіз та систематизація найбільш поширеніших веб-орієнтованих комп'ютерних систем навчання) та інших.

Зокрема, вивченню проблем формування професійної компетентності фахівців охорони здоров'я з використанням інформаційних технологій присвячені роботи Ю. Ляха (дослідження проблем аналізу інформації в біології, медицині та фармації за допомогою статистичних пакетів), М. Мруги (дослідження наукових основ моделювання професійної компетентності майбутнього лікаря), І. Ніженковської (організація самостійної роботи студентів фармацевтів за допомогою сучасних інформаційних технологій), Т. Реви (визначення провідних тенденцій розвитку фармацевтичної освіти в Україні), Н. Стучинської (дослідження інформатичної компетентності студентів медичних спеціальностей в контексті використання інноваційних навчальних технологій), І. Хаімзона (розроблення методичних рекомендацій до практичних занять з медичної інформатики) та інші.

Метою статті $€$ аналіз особливостей систем управління навчальними матеріалами та виклад загальних принципів їх застосування в процесі інформатичної підготовки студентів медичних університетів.

\section{МЕТОДИ ДОСЛІДЖЕННЯ}

Для виконання поставлених завдань було використано теоретичні та емпіричні методи наукових досліджень, а саме:

1) метод системного аналізу, порівняння та узагальнення для теоретичного обгрунтування й розроблення теоретико-методичного супроводу інформатичної підготовки відповідно до їі функцій та ролі у структурі фахової підготовки майбутнього лікаря;

2) бібліосемантичний метод - для вивчення психолого-педагогічної, наукової літератури, нормативних документів з питань інформатичної підготовки студентів медичних ЗВО та використання систем управління навчальними матеріалами;

3) емпіричні методи - бесіди зі студентами та викладачами, аналіз способів використання систем управління навчальними матеріалами в процесі інформатичної підготовки студентів медичних 3ВО;

4) моделювання - для розроблення структури базових концептів у використанні систем управління навчальними матеріалами та аналізу їх функціональних можливостей.

\section{РЕЗУЛЬТАТИ ДОСЛІДЖЕННЯ ТА ЇХ ОБГОВОРЕННЯ}

У галузевих стандартах вищої освіти України до загальних компетентностей фахівця в галузі охорони здоров'я різних рівнів (бакалавра, магістра, доктора філософії), віднесено навички використання інформаційних і комунікаційних технологій, а саме: інформаційного пошуку, створення баз даних, використання мереж і засобів інформаційного забезпечення, обміну інформацією, опрацювання даних, візуалізації медичних зображень, роботи в графічних редакторах та з технологіями презентації та інтерпретації статистичних даних тощо. Акумулюючи результати попередніх наукових пошуків (Микитенко, 2019), можна окреслити один із підходів до визначення сутності IT-компетентності медичного працівника, котра $\epsilon$ внутрішньо-особистісною характеристикою, яка обмежується сферою діяльності та $\epsilon$ комплексом набутих знань, умінь та навичок з використання ресурсів, необхідних для збирання, опрацювання, зберігання та розповсюдження даних для здійснення професійної діяльності в галузі охорони здоров'я.

Як відомо, основними компонентами методичної системи навчання будь-якої дисципліни є: цілі навчання, зміст, методи, організаційні форми, засоби.

Під час визначення цілей навчання інформатичних дисциплін у закладі вищої освіти з використанням систем управління навчальними матеріалами потрібно враховувати загальновідомі цілі навчального процесу: освітні (формування у студентів наукових знань, спеціальних і загально навчальних умінь і навичок), розвиваючі (розвиток мислення, пам'яті, творчих здібностей), виховні (формування наукового світобачення, моралі, естетичної культури тощо). Основними завданнями інформатичної підготовки студентів медичних ЗВо є: формування та розвиток знань, умінь і навичок, необхідних для ефективного використання системного та прикладного програмного забезпечення у галузі охорони здоров'я; ознайомлення з можливостями сучасних інформаційно-комунікаційних технологій у галузі охорони здоров'я, основами телемедицини та перспективами розвитку комп'ютерних технологій; розвиток умінь самостійно опановувати програмні засоби медичного та загального призначення, оновлювати раніше набуті знання та застосовувати 
їх у професійній діяльності; опанування комп'ютерними технологіями візуалізації та статистичного аналізу даних медикобіологічних досліджень; засвоєння концепції баз даних, ознайомлення із спеціалізованими базами даних доказової медицини; пояснення принципів формалізації і алгоритмізації медичних та основ моделювання в медицині; формування навичок розробки систем підтримки прийняття рішень в медицині; ознайомлення із можливостями Web-технологій та основами захисту даних.

Саме наслідком реалізації цих завдань і має буди сформована IT-компетентність, яка забезпечує можливість успішного та ефективного вирішення задач в майбутній професійній діяльності.

Зміст навчання - це система наукових положень, оволодіння якими забезпечує основу для всебічного розвитку фахівця, формування його мислення, пізнавальних інтересів та підготовки до професійної діяльності.

Метод навчання - впорядкований спосіб взаємопов'язаної діяльності суб'єктів навчального процесу, спрямований на досягнення цілей навчання, можуть використовуватись: словесний, наочний, дискусійний, практичний, метод проблемного навчання, метод диференційованого навчання, евристичний.

Методи контролю можуть бути: усний та письмовий контроль засвоєння теоретичного матеріалу; контроль здобуття практичних умінь та навичок; контроль виконання самостійної роботи; підсумковий контроль.

Що стосується форм організації навчання, то системи управління навчальними матеріалами можуть застосовуватись майже до всіх (фронтальні, колективні, групові, парні, індивідуальні), але найбільший вплив здійснюють на групові та колективні форми це пов'язано з тим, що перш за все використання цих систем спрощує організацію співпраці суб'єктів навчального процесу та розширює можливості їх взаємодії.

Розглядаючи компоненти методичної системи навчання, окремої уваги потребують засоби, оскільки існує широкий вибір систем управління навчальними матеріалами. Для порівняння виокремлено дві з них, а саме: систему управління навчальними матеріалами MOODLE та хмарно-орієнтовану систему управління навчальними матеріалами Google Classroom.

MOODLE (Modular Object Oriented Dictance Learning Environment) - система управління навчальними матеріалами (LCMS - Learning Content Management Systems). За допомогою цієї системи можна створювати електронні навчальні курси і проводити як аудиторне (очне) навчання, так і навчання на відстані (заочне/дистанційне). Як зазначено в праці (Франчук, 2020), система MOODLE володіє основними критеріями, що висуваються до систем управління навчальними матеріалами та які обумовлюють наявність певних функціональних характеристик, зокрема такі, як:

- функціональність - набір атрибутів, що відносяться до функцій програмного забезпечення та їх особливостей (форум, чат, аналіз активності користувачів, управління курсами та навчальними групами тощо);

- надійність - зручність адміністрування та управління навчанням, простота оновлення вмісту, захист облікових записів та даних про користувачів від зовнішніх втручань тощо;

- стабільність - високий рівень стійкості функціонування системи відносно різних режимів роботи та активності користувачів;

- вартість - витрати на впровадження, наповнення матеріалами електронних курсів і супровід - мінімальні, а сама система є безкоштовною;

- відсутність обмежень за кількістю ліцензій для користувачів;

- модульність - наявність в навчальних курсах набору блоків матеріалу, які можуть бути використані в інших курсах;

- наявність вбудованих засобів публікації та редагування навчальних матеріалів, інтеграції різноманітних освітніх матеріалів різного призначення;

- підтримка міжнародного стандарту SCORM (Sharable Content Object Reference Model) - основи обміну електронними курсами, що забезпечує перенесення інформаційних ресурсів до інших систем;

- наявність системи аналізу, перевірки та оцінювання знань студентів у режимі он-лайн (тести, завдання, контроль активності на форумах);

- зручність і простота використання та навігації - інтуїтивно зрозумілі правила використання системи (можливість легко знайти меню допомоги, простота переходу від одного розділу до іншого, спілкування з викладачем тощо).

За допомогою даної системи до навчального курсу можна додавати такі ресурси, як: Напис, Текстова сторінка, Гіперпосилання, Доступ до файлів, Пакет IMS (Information Management System - інформаційна управлінська система). Також за допомогою цієї системи можна додавати такі елементи курсу: LAMS (Learning Activity Managment System), Wiki, База даних, Глосарій, Завдання, Опитування, Семінар, Тест, Урок, Форум, Чат та інші. Якщо ж користувачу недостатньо цих можливостей для організації навчальної діяльності, то є можливість додати інші модулі, які не включені до офіційної версії системи.

Google Classroom - хмаро-орієнтована система управління навчальними матеріалами, розроблена компанією Google для закладів освіти, призначенням якої $\epsilon$ спрощення створення та розподілу завдань з використанням хмароорієнтованих сервісів. В систему інтегровані: Google Drive (створення, збереження та розповсюдження матеріалів); Google Docs, Sheets, Slides, Forms (створення та редагування текстових файлів, електронних таблиць слайдів та форм (тестів, анкет)); Gmail (поштовий клієнт), Google Calendar (планування освітнього процесу), а також пошукова система Google для допомоги у пошуку додаткових даних. За допомогою системи Google Classroom можна забезпечити спілкування між учасниками навчального процесу в режимі реального часу.

Використання Google Classroom надає викладачу наступні можливості:

- створення та адміністрування навчального курсу;

- зарахування студентів на курс;

- створення різних типів завдань (тестів, запитань);

- публікація навчальних матеріалів (відео, аудіо, електронні книги, презентації, тощо); 
- поширення оголошень та обмін повідомленнями;

- планування он-лайн семінарів, лекцій, практичних занять;

- ведення електронного журналу.

3 метою організації дистанційного навчання для студентів з дисципліни «Медична інформатика» розроблено відповідні навчальні курси (рис. 1). Для кожного курсу автоматично створюється окрема папка в обліковому записі Google Drive, куди викладач та студенти можуть подавати документи у вигляді посилання на файл зі свого диска або завантажити файл з комп'ютера.

Для кожної теми створено категорію із таким наповненням: теоретичні матеріали та запитання за темою заняття, завдання для практичної роботи (окремо можна встановлювати вагу кожного завдання та максимальну оцінку), програмний засіб для роботи (у разі потреби), тест.

$\equiv$ Medical informatics (Medical) отік завдання Люди оцінки

Topic 11. Formalization and algorithmization of ... :

\begin{tabular}{|c|c|}
\hline (1) Algorithm Flowchart editor & змінено 15 лист. 2020 р. $\quad$ : \\
\hline Practice 11. For malization and algor ithmizati... & змінено 16 лист. 2020 р. \\
\hline Test & иліков ано 19 лист. $202 .$. \\
\hline
\end{tabular}

Topic 10. Interpolation and approximation of st... :

(2)

\begin{tabular}{lc}
\hline (1) Lecture. Computer-aided decision support ... & змінено 19 лист. 2020 р. \\
\hline 固 Prectice 10. Interpolation and approximatio... & Опубліков ано 16 лист. 202... \\
\hline 固 Test 10. & Опубліков ано 16 лист. 202...
\end{tabular}

Рис. 1. Фрагмент наповнення матеріалами навчальної теми

Створити тести можна за допомогою Forms, зокрема доступні такі типи тестових завдань: з одним варіантом відповіді, множинного вибору, коротка відповідь, на відповідність (рис. 2).

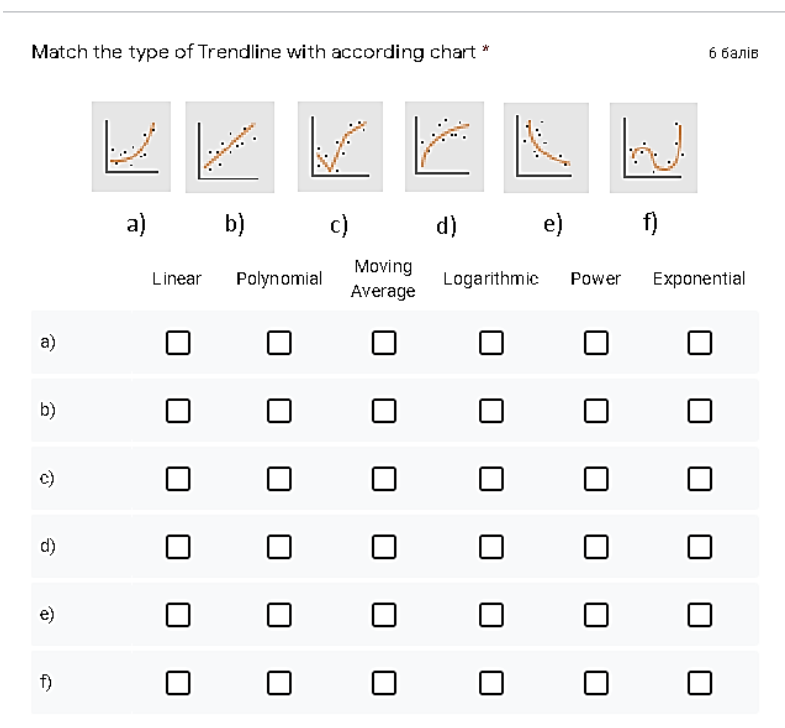

Рис. 2. Приклад тестового завдання «На відповідність»

Звіт про виконані практичні завдання або тести студенти надсилають викладачу скориставшись для цього елементом «Завдання» або «Тест», відповідно. Після чого відбувається оцінювання через пункт меню «На перевірку» (рис. 3).

Також, при необхідності можна скористатись електронним журналом для перегляду оцінок студентів, додавання коментарів та контролю кожного окремого заняття чи теста (рис. 4).

В системі автоматично створюється календар для кожного курсу, де відображаються терміни виконання кожного завдання, крім того використовуючи налаштування календаря викладач має можливість запланувати та призначати онлан зустріч за допомогою сервісу «Meet». 
(1) Kурси

$\square$ Календар

\section{Викладає}

田 На перевірку

(M) Медична інформатика (мед. ...

M Medical informatics (Medical)

(2) Архівовані курси

हु) Налаштування

На перевірку Перевірені

усі заняття

Термін не вказано

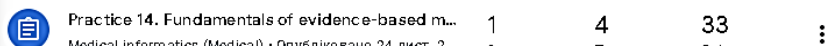
Medical informatics (Medical) • Опүбліковано 24 лист. 2... З здав $\quad$ Призначено Оцінено

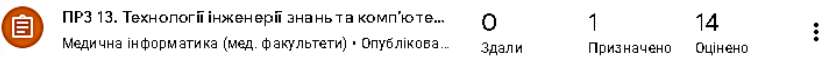

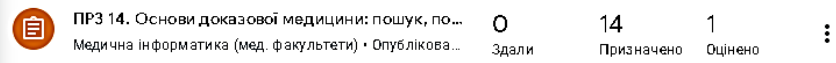

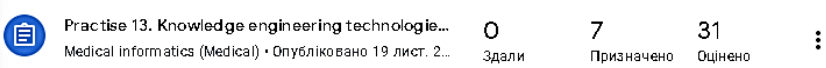

Рис. 3. Оцінювання практичних робіт та тестів

\begin{tabular}{|c|c|c|c|c|c|c|c|c|}
\hline$\equiv$ & Medical informatics & $s(N$ & cal) & Пот & Завдання & Люди & & \\
\hline & & & $\begin{array}{l}\text { Термін не ... } \\
\text { Practice } \\
14 . . .\end{array}$ & $\begin{array}{l}\text { Термін не ... } \\
\text { Practise } \\
13 . . .\end{array}$ & $\begin{array}{l}\text { Термін не ... } \\
\text { Test } 11 .\end{array}$ & $\begin{array}{l}\text { Термін не } \\
\text { Test } 12 .\end{array}$ & $\begin{array}{l}\text { Термін не ... } \\
\text { Practice } \\
12 \ldots . .\end{array}$ & $\begin{array}{l}\text { Термін не ... } \\
\text { Test } 10 .\end{array}$ \\
\hline & Сортувати за прізвищем & $\checkmark$ & 35 & 35 & 35 & 35 & 35 & 35 \\
\hline \multirow[t]{4}{*}{$\because$} & Середня оцінка курсу & & 4,36 & 4,61 & 4,61 & 4,23 & 4,03 & 3,84 \\
\hline & & & 5 & 4 & 4 & 4 & 5 & $\begin{array}{l}4 \\
\text { Не здано }\end{array}$ \\
\hline & & & 5 & 4 & 5 & 4 & 5 & 4 \\
\hline & & & & & & & & $\begin{array}{l}\text { о } \\
\text { Не здано }\end{array}$ \\
\hline
\end{tabular}

Рис. 1. Фрагмент електронного журналу

3 метою встановлення системи з найбільш задовільними функціональними характеристиками, які необхідні для організації та підтримки процесу інформатичної підготовки студентів медичних 3ВО, здійснено порівняльну характеристику LCMS Moodle та Google Classroom (табл. 1).

Таблиця 1

Порівняння функціональних можливостей LCMS Moodle тa Google Classroom

\begin{tabular}{|c|c|c|c|}
\hline № & Функціональні можливості & LCMS Moodle & Google Classroom \\
\hline 1. & Наявність власного домену & + & - \\
\hline 2. & Редактор навчальних курсів & + & + \\
\hline 3. & Облікові записи користувачів & + & + \\
\hline 4. & Управління групами & + & - \\
\hline 5. & Інтеграція з зовнішніми сервісам & + & + \\
\hline 6. & Експорт та імпорт даних про користувача & + & - \\
\hline 7. & Наявність вбудованих текстових, табличних редакторів, тощо & - & + \\
\hline 8. & $\begin{array}{l}\text { Розміщення навчальних матеріалів у форматах .doc, .odt, } \\
\text {.html, .pdf }\end{array}$ & + & + \\
\hline 9. & Створення завдань та опитувань & + & + \\
\hline 10. & Створення стандартних тестових завдань & + & + \\
\hline 11. & Створення додаткових типів тестових завдань & + & - \\
\hline 12. & Банк тестових завдань & + & - \\
\hline 13. & Система аналізу тестових завдань & + & - \\
\hline 14. & Журнал оцінок & + & + \\
\hline 15. & Засоби для он-лайн зв'язку & - & + \\
\hline 16. & Засоби спільної роботи над файлами & - & + \\
\hline 17. & Засоби для групового зв'язку (форум, чат) & + & + \\
\hline 18. & Архів навчальних курсів & + & + \\
\hline 19. & Календар подій & + & + \\
\hline 20. & Захист персональних даних & + & + \\
\hline \multicolumn{2}{|c|}{ Bcboro } & 17 & 14 \\
\hline
\end{tabular}


Очевидно, що за запропонованими функціональними характеристиками вищий рейтинг має LCMS Moodle. Однак варто зауважити, що на відміну від LCMS Moodle в Google Classroom опрацювання файлів здійснювати значно простіше, шляхом редагування та публікування їх в навчальному курсі з Google Drive, що позбавляє від виконання багатьох рутинних операцій з даними. Оскільки LCMS Moodle має обмежений простір для зовнішнього завантаження файлів, а також відсутні будь-які вбудовані засоби створення презентацій та електронних таблиць, це обумовлює використання зовнішніх ресурсів, тих самих Google Docs, Sheets, Slides, Forms. Захист навчальних матеріалів забезпечується на високому рівні в обох системах, в LMCS Moodle - шляхом створення ресурсу «Сторінка», котрий вбудовує файл в сторінку курсу, в Google Classroom налаштуванням прав на перегляд файлу.

Аналізуючи кросплатформність можна зазначити, що LCMS Moodle $€$ багато-платформною системою, a Google Classroom в свою чергу функціонує на базі iOS, Android та веб-браузера, однак саме мобільний додаток останньої системи адаптований та більш інтуїтивний для використання. До того ж, облікові записи користувачів, створені в Google Classroom під власним доменом, реалізують можливість використання всіх додатків системи Google та отримання додаткового місця на локальному диску.

\section{ВИСНОВКИ ТА ПЕРСПЕКТИВИ ПОДАЛЬШИХ ДОСЛІДЖЕНЬ}

Системи управління навчальними матеріалами в значній мірі оптимізують освітній процес, спрощують презентацію навчальних матеріалів, розширюють можливості використання різних сервісів глобальної мережі Інтернет, пришвидшують опрацювання великих обсягів навчального контенту, забезпечують раціональне використання часу та ресурсів. Розглянуті системи, LCMS Moodle та Google Classroom, мають споріднене завдання - організація та управління навчальним процесом, однак мають певні відмінності в низці функціональних можливостей. Але варто зазначити, що комбіноване використання сильних сторін цих систем дозволить компенсувати їх недоліки.

У сучасній системі організації навчального процесу в медичних закладах вищої освіти застосування технологій дистанційного навчання $€$ невід'ємною умовою забезпечення якісної підготовки майбутніх фахівців. Використання систем управління навчальними матеріалами, зокрема, хмарних сервісів розширює можливості організації дистанційного навчання, надає нові можливості для більш активного залучення студентів в освітній процес, сприяє підвищенню рівня загальнокультурної обізнаності майбутніх фахівців.

Перспективи подальших досліджень спрямовані на пошук нових методів та інструментів, які сприятимуть підвищенню ефективності інформатичної підготовки студентів медичних 3 ВО.

1. About Google Classroom. URL: https://support.google.com/edu/classroom/answer/6020279?hl=ru\&visit_id= 637457434090216935- 41323792\&rd=1 (Last accessed: 01.02.2021).

2. About Moodle. URL: https://docs.moodle.org/310/en/AboutMoodle (Last accessed: 01.02.2021).

3. Mykytenko P.V., Lapinskyi V.V. Analysis of the genesis of problems in the formation of it-competence of foreign students in the higher medical educational system. Ukrainian pedagogical journal. 2019. № 4. P. 107-119.

4. Биков В.Ю., Вернигора, С.М., Гуржій А.М., Новохатько, Л.М., Спірін О.М., Шишкіна М.П. Проєктування і використання відкритого хмаро орієнтованого освітньо-наукового середовища закладу вищої освіти. Інформаційні технології $i$ засоби навчання. 2019. 6 (74). С. 1-19.

5. Гуржій А.М., Карташова Л.А., Лапінський В.В. Інформатизація загальної середньої освіти в Україні. Доклады ХІІІ Международной научной конференции «Современные достижения в науке и образовании», Нетания (Израиль). 2018. C. 9-13.

6. Жалдак, М. І. Деякі особливості україномовної інформатичної термінології. Науковий часопис НПУ імені М.П. Драгоманова. Серія 2. Комп'ютерно-орієнтовані системи навчання, 2019.21 (28), С. 3-9.

7. Лях Ю.Е., Гурьянов В.Г., Хоменко В.Н., Панченко О.А.. Основы компьютерной биостатистики: анализ информации в биологии, медицине и фармации статистическим пакетом MedStat. Донецьк: Папакица, 2006. 211 с.

8. Морзе Н.В., Варченко-Троценко Л.О. Використання шікітехнології для організації навчального середовища сучасного університету. Відкрите освітнє е-середовище сучасного університету. 2015. № 1. С. 115-125.

9. Мруга М.Р. Структурно-функціональна модель професійної компетентності майбутнього лікаря як основа діагностування його фахових якостей: автореф. дис... канд. пед. наук: 13.00.04. / Центр. ін-т післядиплом. пед. освіти АПн України. Київ, 2007. 21 с

10. Ніженковська І.В., Головченко О.І., Бут І.О. Організація самостійної роботи студентів фармацевтичного факультету при вивченні органічної хімії за допомогою сучасних інформаційних технологій-засобами блог-технологій. Матеріали XVI Всеукр. наук.-практ. конф. з міжнар. участю. Нац. мед. ун-т імені І.Я. Горбачевського. Тернопіль: ТНМУ. 2019. С. 119120.

11. Рева Т.Д. Тенденції професійної підготовки фармацевтів в Україні. Вісник Національного Авіаційного Університету. 2016. 68(3). С. 105-110.

12. Семеріков С.О., Кислова М.А., Словак К.І. Розвиток мобільного навчального середовища як проблема теорії і методики використання інформаційно-комунікаційних технологій в освіті. Інформаційні технології і засоби навчання. 2014. Т. 42, Вип. 4. С. 1-19.

13. Спірін О.М., Вакалюк Т.А. Критерії добору відкритих web-орієнтованих технологій навчання основ програмування майбутніх учителів інформатики. Інформаційні технології і засоби навчання. 2017. №4 (60). С. 275-287.

14. Стучинская Н.В., Калибабчук В.А., Овчаренко В.Ю. Исследование информатической компетентности студентов 1-го курса НМУ имени А.А. Богомольца в контексте использования инновационных учебных технологий. Инновационное развитие современной науки. 2014.С. 9-12. 
15. Триус Ю.В, Сотуленко О.О. Створення системи підтримки дистанційного навчання медичних працівників на базі Moodle. Автоматизація та комп'ютерно-інтегровані технології у виробництві та освіті: стан, досягнення, перспективи розвитку: матеріали Всеукр. наук.-практ. Інтернет-конф. (АКІТ-2017) ЧНУ ім. Б. Хмельницького. Черкаси. 2017. C. 259-261.

16. Франчук В.М. Методика навчання інформатичних дисциплін в педагогічних університетах з використанням веборієнтованих систем: монографія. Київ: Вид-во НПУ імені М. П. Драгоманова. 2020. 434 с.

17. Хаїмзон І.І. Медичні знання та прийняття рішень в медицині. Вінниця: ВНТУ, 2007. 180 с.

\section{References}

1. About Google Classroom. (n.d.). support.google.com. Retrieved from https://support.google.com/edu/classroom/answer/6020279?hl=ru\&visitid=637457434090216935-841323792\&rd=1 [in English].

2. About Moodle. (n.d.). docs.moodle.org. Retrieved from https://docs.moodle.org/310/en/AboutMoodle [in English].

3. Bykov V.lu., Vernyhora, S.M., Hurzhii A.M., Novokhatko, L.M., Spirin O.M., Shyshkina M.P. (2019) Proiektuvannia i vykorystannia vidkrytoho khmaro oriientovanoho osvitno-naukovoho seredovyshcha zakladu vyshchoi osvity [The Design and Use of the Open Cloud Based Learning and Reserch Environment of a University]. Informatsiini tekhnolohii $i$ zasoby navchannia - Information Technologies and Learning Tools, 6 (74), 1-19. [in Ukrainian].

4. Chaimzon I.I. (2007) Medychni znannia ta pryiniattia rishen v medytsyni [Medical knowledge and decision making in medicine]. Vinnitsa: VNTU. [in Ukrainian].

5. Franchuk V.M. (2020) Metodyka navchannia informatychnykh dystsyplin v pedahohichnykh universytetakh z vykorystanniam veb-oriientovanykh system [Methods of teaching computer science disciplines in pedagogical universities using web-oriented systems]. Kyiv: Drahomanov National Pedagogical University Publishing House. [in Ukrainian].

6. Hurzhii A.M., Kartashova L.A., Lapinskyi V.V. (2018). Informatyzatsiia zahalnoi serednoi osvity v Ukraini [Informatization of general secondary education in Ukraine]. Proceedings fromthe XIII International Scientific Conference «Modern Advances in Science and Education». (pp. 9-13). Netanya. [in Ukrainian].

7. Lyakh YuE, Guryanov VG, Khomenko VN. (2006) Osnovb kompiuternoi byostatystyky: analyz ynformatsyy $v$ byolohyy, medytsyne y farmatsyy statystycheskym paketom MedStat [The basics of computer biostatistics: the analysis of information in biology, medicine and pharmacy by statistical package Medstat]. Donethsk. [in Russian].

8. Morze N.V., Varchenko-Trotsenko L.O. (2015) Vykorystannia wikitekhnolohii dlia orhanizatsii navchalnoho seredovyshcha suchasnoho universytetu [Using wiki technology to organize the learning environment of a modern university]. Vidkryte osvitnie e-seredovyshche suchasnoho universytetu - Open educational e-environment of a modern university, № 1, 115-125. [in Ukrainian].

9. Mruha M.R. (2007) Structural-functional model of professional competence of the future doctor as the basis for diagnosing his professional qualities: author's abstract. Extended abstract of candidate's thesis. Kyiv: Center. in-t after the dip. ped Education of the Academy of Pedagogical Sciences of Ukraine. [in Ukrainian].

10. Mykytenko P.V., Lapinskyi V.V. (2019) Analysis of the genesis of problems in the formation of it-competence of foreign students in the higher medical educational system. Ukrainskyi pedahohichnyi zhurnal - Ukrainian pedagogical journal, № 4, 107-119. [in English].

11. Nizhenkovska I.V., Holovchenko O.I., But I.O. (2019) Orhanizatsiia samostiinoi roboty studentiv farmatsevtychnoho fakultetu pry vyvchenni orhanichnoi khimii za dopomohoiu suchasnykh informatsiinykh tekhnolohii-zasobamy bloh-tekhnolohii [The organization of independent work of students of pharmaceutical faculty at studying of organic chemistry by means of modern information technologies - means of blog technologies]. Proceedings from XVI Vseukr. nauk.-prakt. konf. z mizhnar. Uchastiu - XVI All-Ukrainian scientific-practical conf. with international participation. (pp. 119-120). Ternopil: TNMU. [in Ukrainian].

12. Reva T. (2016). Tendentsii profesiinoi pidhotovky farmatsevtiv v Ukraini [Trends in professional training of pharmacists in Ukraine]. Visnyk Natsionalnoho Aviatsiinoho Universytetu - Bulletin of the National Aviation University, 68(3), 105-110. [in Ukrainian].

13. Semerikov S.O., Kyslova M.A., Slovak K.I. (2014) Rozvytok mobilnoho navchalnoho seredovyshcha yak problema teorii $i$ metodyky vykorystannia informatsiino-komunikatsiinykh tekhnolohii v osviti [Development of mobile learning environment as a problem of theory and methods of using information and communication technologies in education]. Informatsiini tekhnolohii i zasoby navchannia - Information Technologies and Learning Tools, 4(42), 1-19. [in Ukrainian].

14. Spirin O.M., Vakaliuk T.A. (2017) Kryterii doboru vidkrytykh web-oriientovanykh tekhnolohii navchannia osnov prohramuvannia maibutnikh uchyteliv informatyky [Criteria for selection of open web-oriented technologies for teaching the basics of programming to future computer science teachers]. Informatsiini tekhnolohii i zasoby navchannia -Information Technologies and Learning Tools, №4 (60), 275-287. [in Ukrainian].

15. Stuchynskaia N.V., Kalybabchuk V.A., Ovcharenko V.Iu. (2014). Yssledovanye ynformatycheskoi kompetentnosty studentov 1-ho kursa NMU ymeny A.A. Bohomoltsa v kontekste yspolzovanyia ynnovatsyonnыkh uchebnukh tekhnolohyi [Research of information competence of 1st year students of NMU named after A.A. Bogomolets in the context of the use of innovative educational technologies]. Ynnovatsyonnoe razvytye sovremennoi nauky - Innovative development of modern science, 9-12. [in Ukrainian].

16. Zhaldak, M.I. (2019). Deiaki osoblyvosti ukrainomovnoi informatychnoi terminolohii [Some features of Ukrainian-language informatics terminology]. Naukovyi chasopys NPU imeni M.P. Drahomanova. Seriia 2. Kompiuterno-oriientovani systemy navchannia - Scientific journal of NPU named after MP Drahomanov. Series 2. Computer-based learning systems, 21 (28), 39. [in Ukrainian].

17. Tryus Yu.V, Sotulenko, O.O. (2017) Stvorennia systemy pidtrymky dystantsiinoho navchannia medychnykh pratsivnykiv na bazi Moodle [Creating a distance learning support system for health professionals based on Moodle]. Proceedings from 
Vseukr. nauk.-prakt. Internet-konf. (AKIT-2017) «Avtomatyzatsiia ta kompiuterno-intehrovani tekhnolohii u vyrobnytstvi ta osviti: stan, dosiahnennia, perspektyvy rozvytku» - All-Ukrainian. scientific-practical Internet conference (AKIT-2017) "Automation and computer-integrated technologies in production and education: state, achievements, development prospects». (pp. 259-261). Cherkasy. [in Ukrainian].

\section{USE OF STUDY MATERIAL MANAGEMENT SYSTEMS IN THE PROCESS OF INFORMATICAL TRAINING OF MEDICAL UNIVERSITY STUDENTS \\ P.V. Mykytenko, I.I. Kucherenko \\ Bogomolets National Medical University, Ukraine}

Abstract.

Formation of the problem. In the work are considered theoretical and practical aspects of application of educational materials management systems. Given the significant pedagogical potential and conditions of today, undoubtedly, the issues of building models, developing methods and techniques and finding effective ways to implement management systems for educational materials in the process of computer training of medical students are relevant.

Methods. A set of scientific research methods was used to perform the tasks of the research, namely: the method of system analysis, bibliosemantic method, empirical methods and modeling.

Results. The expediency of introduction of management systems of educational materials is substantiated and the statement of the general principles of their application is carried out. The components of the methodical system of informatics training are covered, in particular, the goals and objectives of teaching informatics disciplines in medical freelance education are defined. The criteria put forward to the systems of management of educational materials are investigated and the possibilities of their use are analyzed. A number of functional characteristics have been identified in order to establish the most efficient system and their comparative analysis has been carried out.

Conclusions. It is established that LCMS Moodle and Google Classroom have a related task - the organization and management of the learning process, but they also have a number of differences in functionality. However, it is possible to compensate for the lack of certain capabilities through the combined use of individual elements of these systems. In the modern system of organization of the educational process in medical institutions of higher education, the use of distance learning technologies is an integral condition for providing quality training for future professionals. The use of learning materials management systems, in particular, cloud services expand the possibilities of distance learning, provides new opportunities for more active involvement of students in the educational process, helps to increase the level of general cultural awareness of future professionals.

Key words: educational material management system, cloud-oriented system, computer training, distance learning

\section{(cc) BY-NC-SA}

This work is licensed under Creative Commons Attribution-NonCommercial-ShareAlike 4.0 International License. 